\title{
Pengaruh Kompetensi, Kompensasi, Disiplin Kerja terhadap Kinerja Guru pada Lazuardi Global Islamic School
}

\author{
Asep Suherman \\ Fakultas Ekonomi, Universitas Pamulang \\ Jalan Surya Kencana No.1 Pamulang, Tangerang Selatan, Banten, Indonesia \\ dosen02438@unpam.ac.id \\ Diterima: 06-11-2020 | Disetujui: 07-07-2021 | Dipublikasi: 31-07-2021
}

\begin{abstract}
ABSTRAK
Tujuan penelitian ini adalah untuk mengetahui pengaruh variabel kompetensi, kompensasi, disiplin kerja baik secara parsial dan simultan terhadap kinerja guru. Metode yang digunakan dalam penelitian ini adalah deskriptif kuantitatif dengan uji regresi berganda menggunakan program SPSS versi 22. Populasi dalam penelitian ini adalah guru di Lazuardi Global Islamic School yang berjumlah 105 guru. Hasil penelitian ini menunjukkan,secara parsial kompetensi dan kompensasi berpengaruh positif dan signifikan terhadap kinerja guru, namun disiplin kerja tidak signifikan memengaruhi kinerja guru. Selanjutnya, secara simultan, variabel kompetensi, kompetensi dan disiplin kerja secara bersama-sama berpengaruh signifikan terhadap kinerja guru. Saran yang diberikan berdasarkan hasil penelitian ini adalah, sebaiknya guru meningkatkan kompetensinya dalam proses belajar mengajar, manajemen sekolah lebih meningkatkan kompensasi dalam bentuk insentif finansial bagi guru, tingkat disiplin guru sudah cukup baik, namun sebaiknya guru lebih meningkatkan komunikasi kepada manajemen sekolah jika menghadapi suatu permasalahan, sebab dari hasil penelitian variabel disiplin belum memengaruhi kinerja, upaya mendisplinkan guru dalam proses belajar mengajar harus menjadi program prioritas manajemen sekolah.
\end{abstract}

\section{Kata Kunci:}

Kompetensi; Kompensasi; Disiplin Kerja; Kinerja Guru

\begin{abstract}
The purpose of this study was to determine the effect of competency variables, compensation, work discipline partially and simultaneously on teacher performance. The method used in this research is quantitative descriptive analysis with multiple regression tests using the SPSS version 22 program. The population in this study was 105 teachers at Lazuardi Global Islamic School. The results of this study indicate that partially competence and compensation have a positive and significant effect on teacher performance, but work discipline does not significantly affect teacher performance. Furthermore, simultaneously, the competency, competence, and work discipline variables together have a significant effect on teacher performance. The suggestions given based on the results of this study are that teachers should improve their competence in the teaching and learning process, school management should increase compensation in the form of financial incentives for teachers, the level of teacher discipline is good enough, but teachers should improve their communication with school management if they face a problem., because from the research results the discipline variable has not affected performance, efforts to discipline teachers in the teaching and learning process must be a priority program of school management.
\end{abstract}

Keywords:

Competence; Compensation; Work Discipline; Teacher Performance 


\section{PENDAHULUAN}

Pendidikan memegang peranan penting dalam upaya mewujudkan kualitas sumber daya manusia. Penyelenggaraan pendidikan yang berkualitas tidak terlepas dari peran guru dan kepala sekolah (Jayanto, Susanto, \& Mulyadi, 2020; Panjaitan, 2016). Kualitas peserta didik yang akan menjadi penerus bangsa sangat berpengaruh terhadap kualitas yang dimiliki oleh guru (Catio, Yusuf, \& Aldy, 2013). Guru merupakan salah satu penggerak dan pelaksana dalam kegiatan pembelajaran di sekolah, tanpa guru yang disebut sebagai tenaga kependidikan maka pelaksanaan pembelajaran tidak berjalan sebagaimana yang diharapkan dimaksud (Jayanto et al., 2020).

Sekolah sebagai suatu sistem memiliki komponen-komponen yang berkaitan satu sama lainnya serta berkonstribusi pada pencapaian tujuan pendidikan. Komponen-komponen tersebut adalah kurikulum, bahan ajar, siswa sebagai peserta didik, guru sebagai tenaga pendidik, kepala sekolah, sarana dan prasarana, serta tenaga kependidikan lainnya (Presilawati, 2016). Guru merupakan elemen kunci dalam sistem pendidikan, khususnya di sekolah. Semua komponen lain, mulai dari kurikulum, sarana-prasarana, biaya, dan sebagainya tidak akan banyak berarti apabila esensi pembelajaran yaitu interaksi guru dengan peserta didik tidak berkualitas. Semua komponen lain, terutama kurikulum akan "hidup" apabila dilaksanakan oleh guru. Begitu pentingnya peran guru dalam mentransformasikan input-input pendidikan, sampai-sampai banyak pakar menyatakan bahwa di sekolah tidak akan ada perubahan atau peningkatan kualitas tanpa adanya perubahan dan peningkatan kualitas guru (Mutakin, 2015). Sekolah diberi kebebasan memilih strategi, metode, dan teknik pembelajaran yang sesuai dengan karakteristik mata pelajaran, siswa, guru, dan kondisi nyata sumber daya, yang tersedia di sekolah. Secara umum, metode pembelajaran yang berpusat pada siswa (student centered) lebih mampu memberdayakan pembelajaran siswa (Presilawati, 2016).

Kinerja merupakan isu global saat ini, hal itu terjadi sebagai konsekuensi dari tuntutan masyarakat akan kebutuhan akan pelayanan yang prima atau pelayanan yang bermutu tinggi (Parman, Mahfudnurnajamuddin, Nujum, \& Su'un, 2020). Pada ranah pendidikan, profesionalisme guru dituntut agar terus berkembang sesuai dengan perkembangan jaman, ilmu pengetahuan dan teknologi, serta kebutuhan masyarakat termasuk kebutuhan terhadap sumber daya manusia yang berkualitas dan memiliki kapabilitas untuk mampu bersaing di forum regional, nasional maupun internasional(Jayanto, Susanto, \& Mulyadi, 2020). Selain itu, guru dituntut untuk memahami dan mengatur emosi dan perasaan diri serta perasaan siswa untuk menjaga keseimbangan antara pendekatan pengajaran formal dan informal (Kaur, Shri, \& Mital, 2019). Kualitas kinerja guru tampak dari perilaku yang mampu dan siap berperan secara profesional di sekolah dan masyarakat. Kinerja guru seperti hal profesi yang lain dipengaruhi oleh banyak hal (Habibi, 2013). Namun, harus ada keseimbangan antara tugas dan people oriented, supervisi yang ketat dan pendampingan kepada guru untuk mengembangkan dan menjaga kinerja mengajar (Kadtong, Unos, Antok, \& Midzid, 2018).

Kinerja adalah suatu cara untuk mendapatkan hasil yang lebih baik bagi organisasi, kelompok, dan individu dengan memahami dan mengelola pekerjaan sesuai dengan target yang 
direncanakan, standar, dan persyaratan kompetensi yang telah ditentukan. Kinerja dapat dipahami sebagai suatu kerangka kerja dari sasaran yang telah direncanakan, standar dan persyaratan kompetensi yang telah disepakati. Kinerja dapat dilihat sebagai suatu kesepakatan di antara seorang pegawai dengan pimpinannya tentang berbagai harapan pencapaian tujuan organisasi secara keseluruhan (Rokhman \& Supriyoko, 2020). Kinerja guru adalah hasil kerja yang dicapai oleh guru sesuai dengan tanggung jawab dan wewenangnya sebagai seorang guru atau pengajar dalam rangka mencapai tujuan secara baik. Kinerja guru ini merupakan faktor pendukung yang sangat penting di dalam sekolah untuk berkembangnya dan dapat bersaing dengan sekolah lain, bahkan sekolah menjadi yang terdepan dari tahun ketahun (Presilawati, 2016). Kinerja dapat pula diartikan sebagai prestasi kerja atau pelaksanaan kerja, sebagai suatu kesuksesan yang dihasilkan seseorang dalam melaksanakan suatu pekerjaan menurut ukuran yang berlaku, dalam kurun waktu tertentu berkaitan dengan pekerjaan serta perilaku dan tindakannya. Keunggulan kompetitif guru akan tercapai apabila pihak manajemen dapat mengelola jantung aktivitas sekolah dengan mendorong sumber daya manusianya, karena pada dasarnya guru tersebut merupakan komponen penting bagi sekolah untuk menciptakan daya saing yang berkualitas (Presilawati, 2016)

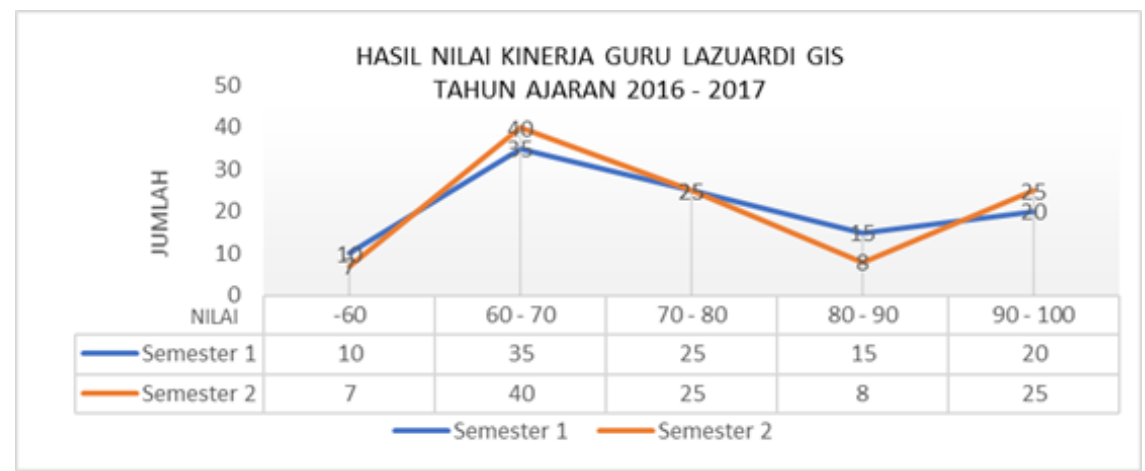

Gambar 1. Kinerja Guru Lazuardi GIS

Berdasarkan data tersebut terlihat hasil penilaian kinerja guru semester 1 dan semester 2 dari 105 guru yang mendapatkan nilai kurang dari 60 sebanyak 7-10 guru, nilai 60-70 sebanyak 35-40 guru dan nilai 70-80 sebanyak 25 guru dan nilai 80-90 sebanyak 15-20 guru dan nilai tertinggi 90 100 sebanyak 20-25 guru.

Guru harus berperan secara aktif dan menempatkan kedudukannya sebagai tenaga profesional yang harus memiliki empat empat kompetensi dasar yaitu kompetensi pedagogik, kepribadian, profesional dan sosial. Kinerja guru sangat penting dalam mewujudkan tujuan pendidikan nasional dan menentukan tinggi rendahnya mutu pendidikan, akan tetapi kinerja guru ini banyak dipengaruhi oleh berbagai faktor baik dari dalam maupun dari luar individu yang bersangkutan (Suaedah, 2020). Guru yang profesional dibangun melalui penguasaan sejumlah kompetensi yang secara nyata diperlukan untuk mendukung pelaksanaan tugas dan pekerjaannya. Kompetensi guru perlu dikembangkan secara simultan sehingga penyelenggaraan pendidikan didukung oleh tenaga pendidik yang professional dalm melaksanakan tugas dan mampu menempatkan diri sesuai jabatan, serta memiliki kepribadian yang mendukung pelaksanaan tugasnya (Lathifah, 2014). 
Kompetensi merupakan seperangkat pengetahuan, keterampilan, dan sikap yang harus dimiliki, dihayati, dikuasai, dan diwujudkan oleh seseorang dalam melaksanakan tugas keprofesionalan tanpa meninggalakan aspek kemampuan pribadi dan kemampuan sosial dalam melaksanakan tugas tugasnya. Kompetensi adalah kemampuan yang harus dimiliki seorang pegawai (individu) untuk dapat melaksanakan suatu pekerjaan (Sari \& Mardjuni, 2018). Kompetensi guru diperlukan dalam memberikan pengajaran. Guru yang memiliki kompetensi tinggi merupakan guru yang profesional yang memiliki keterampilan dan pengetahuan. Kompetensi adalah suatu kemampuan yang dilandasi oleh keterampilan dan pengetahuan yang didukung oleh sikap kerja serta penerapannya dalam melaksanakan tugas dan pekerjaan yang mengacu pada persyaratan kerja yang ditetapkan (Catio \& Sunarsi, 2020). Kompetensi guru menjadikan siswa berkualitas dalam proses belajar mengajar di sekolah (Azmi et al., 2019).

Faktor lain yang mempengaruhi kinerja dari luar diri seorang guru adalah berkaitan dengan seberapa besar tingkat kesejahteraan yang diberikan oleh lembaga. Kinerja guru merupakan hasil yang dicapai oleh guru dalam melaksanakan tugas-tugas yang dibebankan kepadanya, didasarkan atas pengetahuan (knowledge), kecakapan dan keterampilan, pengalaman dan kesungguhan serta efektifitas waktu. Setiap individu yang akan, sedang atau telah menyumbangkan tenaga, waktu dan pikirannya untuk organisasi secara pasti mempunyai harapan mendapatkan feedback yang sesuai dari organisasi sebagai bentuk penghargaan dari prestasi kerjanya, sekaligus sebagai sumber pendapatan untuk memenuhi kebutuhan hidupnya. Tuntutan terhadap tugas dan tanggung jawab guru akan terpenuhi, manakala kondisi psikologis dan sosial serta penghargaan (kompensasi) yang diterima dapat mendukung. Karena pada dasarnya kinerja guru membutuhkan konsentrasi dan kegairahan dalam bekerja, dan kondisi ini dapat terwujud apabila kebutuhan hidup guru dapat terpenuhi secara adil dan layak, sehingga dapat menimbulkan kepuasan, kenyamanan dan ketenangan dalam bekerja, dan pada akhirnya dapat memotivasi guru untuk meningkatkan kinerjanya (Lathifah, 2014).

Kompensasi adalah semua bentuk upah atau imbalan yang berlaku bagi karyawan dan muncul dari pekerjaan mereka, dan mempunyai dua komponen Kompensasi merupakan salah satu alat untuk memotivasi dan sekaligus sebagai jalur pengembangan yang strategis untuk mengoptimalkan sumber daya manusia (SDM) yang bermutu (Suaedah, 2020). Kompensasi merupakan bentuk penghargaan atau balas jasa yang diberikan oleh organisasi kepada pegawainya baik yang berbentuk finansial maupun barang dan jasa pelayanan agar pegawai merasa dihargai dalam bekerja. Pemberian kompensasi merupakan salah satu pelaksanaan fungsi manjemen sumber daya manusia (Rokhman \& Supriyoko, 2020).

Kompensasi menjadi salah satu faktor yang dominan dalam memotivasi seseorang untuk meningkatkan kinerjanya. Dengan diberi kompensasi yang pantas, guru akan dapat memenuhi kebutuhan-kebutuhan fisik, status sosial, dan egoistiknya sehingga memperoleh kepuasan dari profesinya, sehingga guru bisa lebih fokus untuk meningkatkan kinerjanya, yang akhirnya bisa meningkatkan kualitas pembelajaran. Selain oleh kompensasi, kinerja guru juga dipengaruhi oleh 
disiplin kerja. Guru yang memiliki disiplin kerja yang baik mencerminkan tanggungjawabnya yang bagus terhadap tugas-tugasnya, sehingga akan meningkatkan kinerja guru tersebut. Oleh karena itu, disiplin kerja yang baik akan berdampak positif terhadap kinerjanya (Masruroh, Thomas, \& Latifah, 2012). Dengan adanya kompensasi yang memadai dan peningkatan motivasi yang dijalankan berhasil, maka seorang pegawai akan termotivasi dalam pelaksanaan pekerjaan yang dibebankan kepadanya dan berupaya mengatasi permasalahan yang terjadi (Sari \& Mardjuni, 2018). Kompensasi memiliki arti yang khusus bagi guru, mereka mungkin memikirkan kompensasi sebagai imbalan bagi pekerjaan yang memuaskan atau menonjol. Kompensasi dalam sebuah organisasi adalah untuk menarik, memotivasi dan mempertahankan guru yang mempunyai produktivitas dan prestasi kerja yang baik. Oleh sebab itu untuk melaksanakan tujuan-tujuan ini, perusahaan atau organisasi harus menggunakan tiga komponen utama kompensasi, yaitu kompensasi finansial yang berupa gaji pokok, insentif termasuk bonus, serta imbalan lainnya yang tidak berbentuk uang (non-financial reward), seperti cuti sakit, liburan, dan asuransi kesehatan (Lathifah, 2014). Pemerintah harus memperkuat gaji para guru agar para guru mendapatkan kepuasan yang lebih tinggi dalam pekerjaannya. Mereka harus mengalokasikan lebih banyak anggaran untuk gaji guru (Kadtong, Unos, Antok, \& Midzid, 2018).

Tujuan pemberian kompensasi antara lain menjamin penghidupan karyawan, meningkatkan kinerja, meningkatkan harga diri, mempererat hubungan kerja, mencegah keluar/resign dari perusahaan, meningkatkan disiplin kerja, memfasilitasi perusahaan mencapai tujuan, melaksanakan peraturan perundang-undangan yang berlaku (Thaief, Baharuddin, Priyono, \& Idrus, 2015). Kompensasi guru adalah bentuk imbalan dan penghargaan yang berhak diterima guru baik yang berupa imbalan langsung maupun tak langsung sebagai balas jasa atas prestasi dan kinerja guru. Adanya kompensasi menjadi stimulus bagi guru untuk meningkatkan prestasi kerja. Sistem pemberian kompensasi yang tepat dan sesuai sasaran menjamin kesejahteraan guru. Adanya kompensasi tinggi yang diberikan kepada guru dapat meningkatkan kinerja guru (Presilawati, 2016). Dengan pemberian kompensasi yang memadai, maka karyawan akan dapat bekerja dengan tenang dan memusatkan seluruh pikirannya untuk menyelesaikan pekerjaan yang menjadi tanggung jawabnya. Karyawan yang tergolong berpotensi akan mampu mengembangkan potensinya untuk menghasilkan kinerja perusahaan yang baik. Jika hal tersebut dapat terwujud, maka perusahaan akan dapat mencapai tujuannya (Thaief et al., 2015).

Upaya meningkatkan kinerja guru juga dapat dilakukan dengan pemberian disiplin (Suaedah, 2020). Penerapan disiplin berfungsi sebagai pembentuk nilai dan norma individu, penguasaan diri, sikap serta tanggungjawab bagi guru. Selain itu, berbagai aturan atau norma yang ditetapkan oleh suatu lembaga pendidikan memiliki peran yang sangat penting dalam menciptakan kedisiplinan agar para guru atau tenaga kependidikan dapat mematuhi peraturan tersebut. Aturan atau norma itu biasanya diikuti sanksi yang diberikan bila terjadi pelanggaran. Sanksi tersebut bisa berupa teguran baik lisan atau tertulis, skorsing, penurunan pangkat bahkan sampai pemecatan kerja tergantung dari besarnya pelanggaran yang dilakukan oleh guru atau tenaga kependidikan. Hal itu dimaksudkan agar 
para guru atau tenaga kependidikan bekerja dengan disiplin dan bertanggungjawab atas pekerjaannya (Rokhman \& Supriyoko, 2020). Perilaku dan sikap yang dimilikinya serta rasa tanggung jawab terhadap tugas yang diembannya, akan memberikan andil yang besar dalam pencapaian tujuan pendidikan nasional. Perilaku tersebut merupakan salah satu wujud dari disiplin kerja yang sangat dibutuhkan dalam setiap diri individu.

Disiplin merupakan salah satu faktor yang menentukan keberhasilan suatu kegiatan (Catio \& Sunarsi, 2020). Disiplin kerja merupakan salah satu sikap yang perlu diperhatikan dalam usaha meningkatkan kinerja guru dalam mencapai tujuan organisasi. Disiplin kerja merupakan upaya untuk meningkatkan kesadaran dan kesediaan seseorang mentaati semua peraturan perusahaan dan normanorma sosial yang berlaku (Azmi, Sakdiawati, \& Marlibatubara, 2019). Disiplin kerja merupakan tindakan seorang guru untuk mematuhi peraturan-peraturan yang telah disepakati bersama. Tindakan ini bila dilakukan secara benar dan terus menerus akan menjadi kebiasaan yang tertanam dalam perilaku guru dan akan membantu tercapainya kinerja guru yang diharapkan institusi (Presilawati, 2016). Disiplin kerja merupakan sikap dan perilaku taat maupun patuh pada peraturan kerja secara sadar, menerima sangsi dengan sukarela bila melanggar sehingga pegawai akan bekerja dengan efektif dan efisien (Rokhman \& Supriyoko, 2020). Disiplin kerja merupakan sikap mental yang senantiasa untuk menaati segala peraturan dan ketentuan yang telah ditetapkan untuk tujuan tertentu. Dengan disiplin kerja yang baik akan lebih meningkatkan kinerja guru yang pada akhirnya akan dapat meningkatkan mutu pendidikan (Suaedah, 2020).

Disiplin kerja akan menjamin terpeliharanya ketertiban dan kelancaran pelaksanaan tugas, guna memperoleh hasil yang optimal, bagi karyawan akan memperoleh suasana kerja yang menyenangkan yang akan menambah semangat kerja dalam melaksanakan pekerjaannya. Dengan demikian, dengan kondisi kerja yang teratur dan terarah sebagai penerapan disiplin kerja pada karyawan maka akan dapat mempengaruhi kinerja karyawan. Disiplin kerja merupakan alat yang digunakan oleh manajer untuk berkomunikasi dengan karyawan sehingga bersedia untuk mengubah suatu perilaku serta sebagai upaya untuk meningkatkan kesadaran dan kemauan seseorang untuk mematuhi semua. peraturan perusahaan dan norma sosial yang berlaku (Thaief et al., 2015).

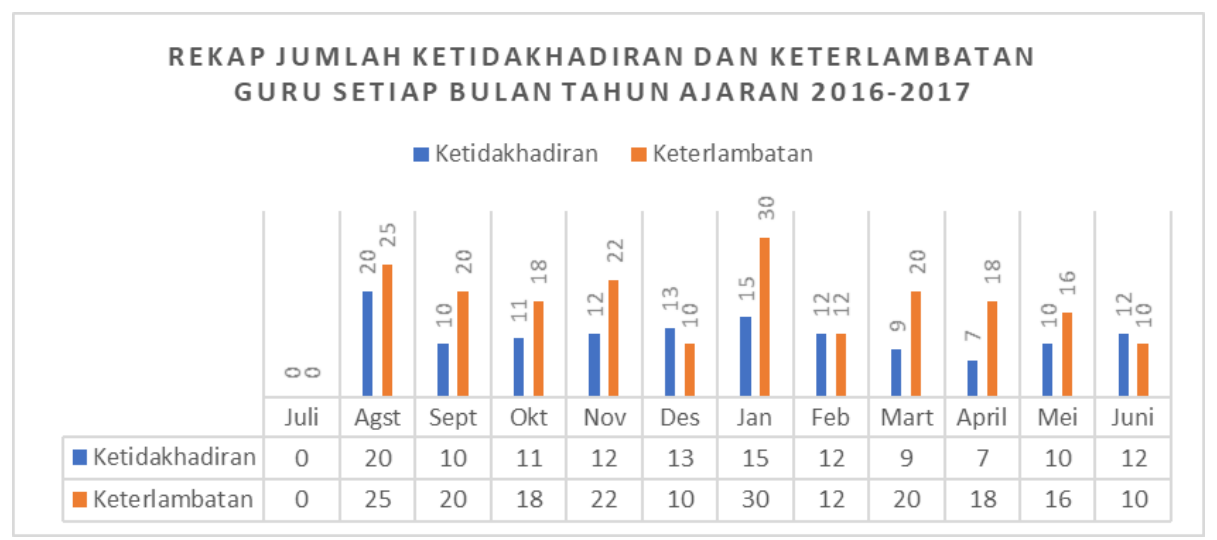

Gambar 2. Data Kedisiplinan Guru Lazuardi GIS 
Berdasarkan grafik pada Gambar 2 terlihat dari ketidakhadiran guru setiap bulanya masih ada guru yang tidak masuk kerja dengan tingkat ketidakhadiran. Adapun keterangan dari wawancara terbuka yang dilakukan peneliti dengan beberapa guru ada beberapa hal yang saat ini terjadi yaitu kompensasi yang diberikan belum sesuai dengan yang diharapkan oleh para guru, dan bonus yang diberikan belum sesuai apa yang diharapkan

\section{METODE RISET}

Penelitian ini menggunakan metode penelitian kuantitatif yang bersifat deskriptif, Sugiyono (2016) mengatakan bahwa populasi merupakan suatu wilayah generalisasi yang terdiri dari objek atau subjek yang menjadi kuantitas dan karakteristik tertentu yang ditetapkan oleh peneliti untuk dipelajari dan kemudian ditarik kesimpulannya. Populasi dari penelitian ini adalah semua guru tetap di Lazuardi Global Islamic School yang berjumlah 105 guru. Sampel yang digunakan dalam penelitian ini adalah nonprobability sampling yaitu sampel jenuh, dengan kata lain, semua guru tetap di Lazuardi Global Islamic School menjadi anggota sampel.

Data diperoleh melalui kunjungan langsung atau survei yang dilakukan di lokasi penelitian, terhadap obyek yang diteliti dan dipandu dengan kuesioner. Selain itu, data ini diambil melalui hasil diskusi dan wawancara dengan guru yang terkait dengan obyek penelitian. Pertanyaan pada angket dibuat berdasarkan skala likert. Data yang telah dikumpulkan dianalisis dengan menggunakan statistik deskriptif, uji asumsi klasik), dan analisis regresi berganda.

Uji Statistik deskriptif adalah statistik yang digunakan untuk menganalisa data dengan cara menjelaskan gambaran data yang telah terkumpul, Sugiyono (2016) menyatakan dalam statistik deskriptif memberikan gambaran data berdasarkan min, median, modus, standar devisi dan varians. Lebih lanjut, Sugiyono (2016) menyatakan analisis regresi linear berganda yaitu regresi yang digunakan untuk mengetahui seberapa besar pengaruh variable independen terhadap variable dependen. Persamaan regresi berganda dalam penelitian ini sebagai berikut:

$$
\mathrm{Y}=\mathrm{a}+\beta 1 \mathrm{X} 1+\beta 2 \mathrm{X} 2+\beta 3 \mathrm{X} 3
$$

Keterangan :

$\begin{array}{llll}\mathrm{Y} & =\text { Kinerja } & \mathrm{X} 1 & =\text { Kompetensi } \\ \mathrm{a} & =\text { Konstanta } & \mathrm{X} 2 & =\text { Kompensasi } \\ \beta 1, \beta 2, \beta 3 & =\text { Koefisien variabel independen } & \mathrm{X} 3 & =\text { Disiplin Kerja. }\end{array}$

\section{HASIL PENELITIAN DAN PEMBAHASAN}

\section{Karakteristik Responden}

1. Jenis Kelamin Responden

Berdasarkan Gambar 3, dapat diketahui $81 \%$ atau 85 orang responden adalah laki-laki dan $19 \%$ atau 20 orang adalah perempuan. 


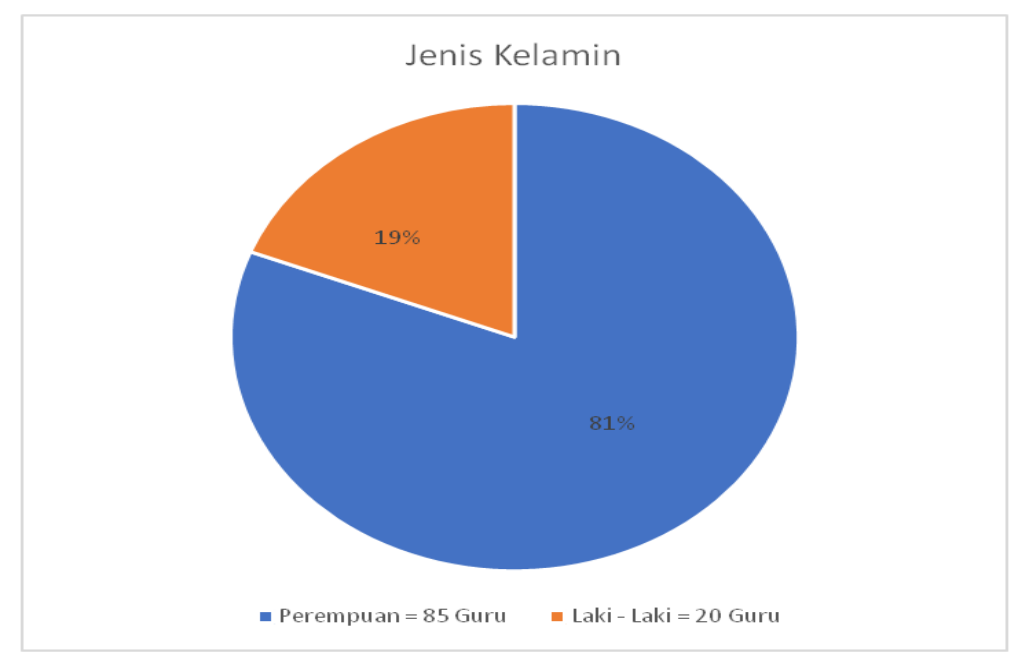

Gambar 3. Proporsi Jenis Kelamin Responden Sumber: Hasil Olah Data Penulis

2. Jenjang Pendidikan Responden

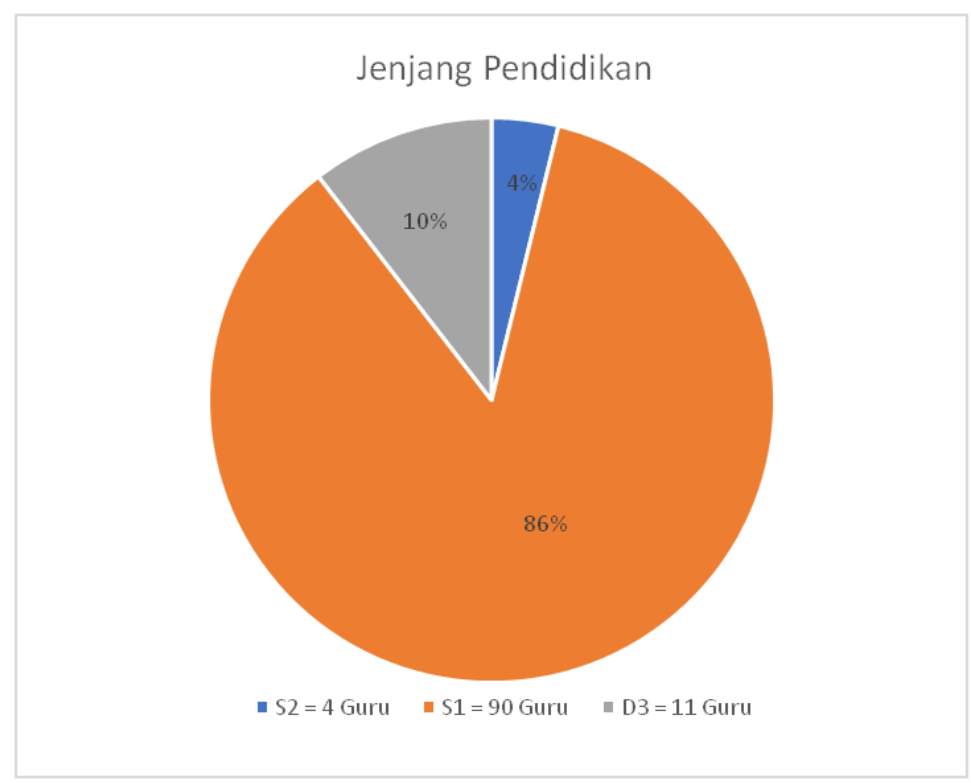

Gambar 4. Jenjang Pendidikan Responden Sumber: Hasil Olah Data Penulis

Berdasarkan Gambar 4, dapat diketahui $10 \%$ responden berpendidikan D.3, $86 \%$ responden berpendidikan S1, dan $4 \%$ berpendidikan $\mathrm{S} 2$.

\section{Statistik Deskriptif}

Hasil pengolahan data dengan statistik deskriptif disajikan pada Tabel 1 berikut:

Tabel 1. Statistik Deskriptif

\begin{tabular}{cccc}
\hline & Mean & Std. Deviation & $\mathrm{N}$ \\
\hline Kinerja Guru & 56.1810 & 4.86309 & 105 \\
Kompetensi & 45.0952 & 3.79150 & 105 \\
Kompensasi & 39.1714 & 5.25221 & 105 \\
Disiplin Kerja & 34.3048 & 2.72497 & 105 \\
\hline
\end{tabular}

Sumber: Hasil Olah Data Penulis 
Tabel 1 menunjukkan, pada variabel Kinerja Guru rata-rata skor jawaban adalah 56.18 dan standar deviasi sebesar 4.86. Variabel Kompetensi rata-rata skor jawaban 45.09 dan standar deviasi sebesar 3.79. Variabel Kompensasi rata-rata skor jawaban 39.17 dan standar deviasi sebesar 5.25, dan pada variabel Disiplin kerja rata-rata skor jawaban 34.30 dan standar deviasi sebesar 2.72.

\section{Uji Asumsi Klasik}

\section{Uji Normalitas}

Hasil uji normalitas data dapat dilihat pada gambar berikut.

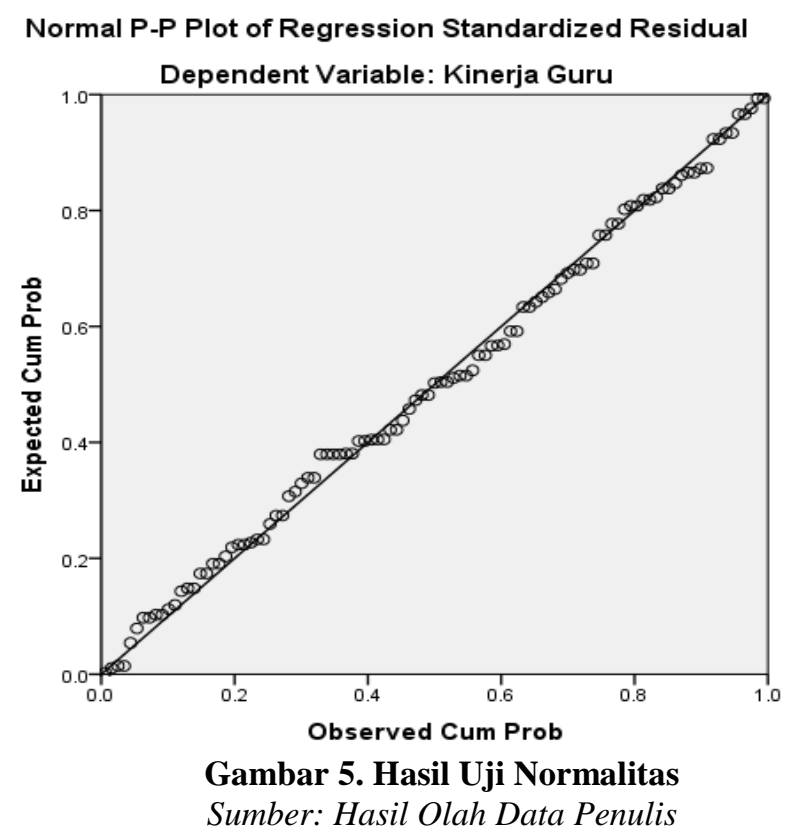

Berdasarkan Gambar 5 terlihat bahwa titik residual menyebar disekitar garis diagonal. Oleh karena itu, dapat disimpulkan data dalam penelitian ini sudah normal dan layak untuk dianalisis lebih lanjut.

\section{Uji Multikoliniearitas}

Hasil uji multikoliniertas dapat dilihat pada tabel 2. Berdasarkan Tabel 2, nilai tolerance semua variabel independen lebih besar dari 0,10 dan nilai VIF semua variabel independen lebih kecil dari 10.00, maka disimpulkan bahwa tidak terjadi masalah multikoliniearitas pada data penelitian.

Tabel 2. Hasil Uji Multikolinieritas

\begin{tabular}{lccc}
\hline & & \multicolumn{2}{c}{ Collinearity Statistics } \\
\cline { 2 - 4 } Model & Tolerance & VIF \\
\hline 1 & (Constant) & .556 & 1.800 \\
& Kompetensi & .694 & 1.440 \\
& Kompensasi & .512 & 1.951 \\
\hline \multicolumn{3}{c}{ Disiplin Kerja } & \multicolumn{3}{c}{ Sumber: Hasil Olah Data Penulis }
\end{tabular}

\section{Uji Heteroskedastisitas}

Uji heteroskedastisitas bertujuan untuk menguji apakah dalam suatu model regresi terdapat persamaan atau perbedaan varians dan residual suatu pengamatan ke pengamatan yang lain (Ghozali, 
2011)(Sugiyono, 2016), Berdasarkan Gambar 6, grafik scatter plot menunjukan bahwa varian dan residual data telah menyebar secara acak, artinya tidak terjadi masalah heteroskedastisitas pada data penelitian. Berikut disajikan hasil uji heteroskedastisitas.

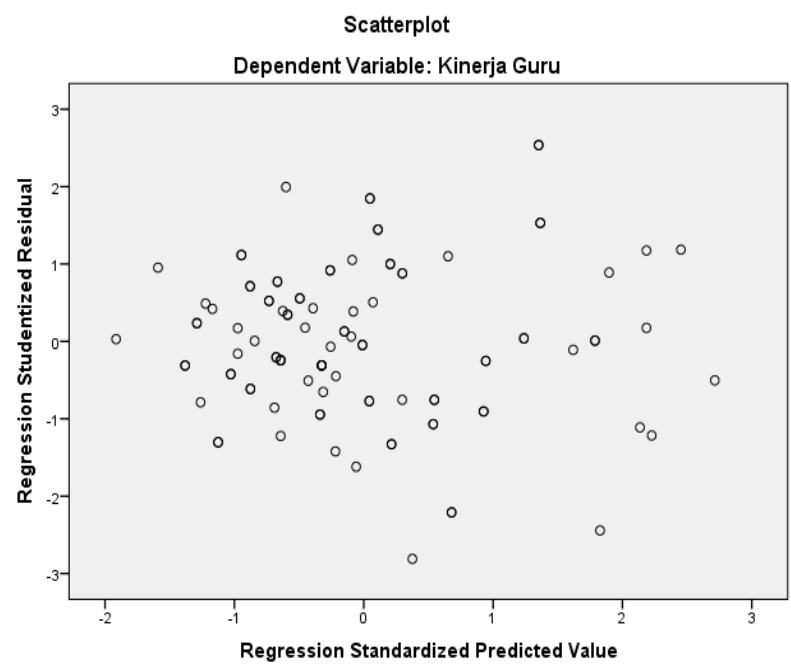

Gambar 6. Hasil Uji Heterokedastisitas Sumber: Hasil Olah Data Penuli

\section{Analisis Regresi Berganda}

Analisis regresi linear berganda digunakan untuk mengetahui seberapa besar pengaruh dari variabel bebas (Kompetensi, Kompensasi, dan Disiplin Kerja) terhadap variabel terikat (Kinerja Guru).

Tabel 3. Hasil Uji Regresi Linear Berganda Coefficients $^{a}$

\begin{tabular}{lrrrrr}
\hline & \multicolumn{2}{c}{$\begin{array}{c}\text { Unstandardized } \\
\text { Coefficients }\end{array}$} & $\begin{array}{c}\text { Standardized } \\
\text { Coefficients }\end{array}$ & & \\
\cline { 2 - 4 } Model & \multicolumn{1}{c}{$\mathrm{B}$} & \multicolumn{1}{c}{ Std. Error } & Beta & \multicolumn{1}{c}{ t } & \multicolumn{1}{c}{ Sig. } \\
\hline 1 1 Constant) & 8.074 & 4.094 & & 1.972 & .051 \\
Kompetensi & .700 & .107 & .546 & 6.545 & .000 \\
Kompensasi & .202 & .069 & .219 & 2.928 & .004 \\
Disiplin Kerja & .251 & .155 & .140 & 1.617 & .109 \\
\hline
\end{tabular}

a. Dependent Variable: Kinerja Guru

Sumber: Hasil Olah Data Penulis

Dari hasil output diatas dapat dilakukan pengujian hipotesis secara linear berganda dengan tiga variabel independen sebagai berikut :

$$
\mathrm{Y}=\mathbf{8 . 0 7 4}+0,700 \mathrm{X} 1+0,202 \mathrm{X} 2+0,251 \mathrm{X} 3
$$

Hasil uji hipotesis 1 dapat dilihat pada Table 3, dengan hasil sebagai berikut:

1. Hasil uji hipotesis 1 , variabel kompetensi mempunyai thitung sebesar 6.545 lebih besar dari tabel 1.659. Pada nilai sig, variabel kompetensi mempunyai tingkat signifikan sebesar 0.000 lebih kecil dari pada 0,05 . Hal ini berarti $\mathrm{H}_{\mathrm{a} 1}$ diterima, artinya variabel kompetensi berpengaruh signifikan terhadap kinerja guru. 
2. Hasil uji hipotesis 2, variabel kompensasi mempunyai thitung sebesar 2.928 lebih besar dari tabel 1.659. Pada nilai sig, variabel kompetensi mempunyai tingkat signifikan sebesar 0.004 lebih kecil dari pada 0,05. Hal ini berarti $\mathrm{H}_{\mathrm{a} 2}$ diterima, artinya variabel variabel kompensasi berpengaruh signifikan secara parsial terhadap kinerja guru.

3. Hasil uji hipotesis 3, variabel disiplin kerja mempunyai $t_{\text {hitung }}$ sebesar 1.617 lebih kecil dari $\mathrm{t}_{\text {tabel }}$ 1.659. Pada nilai sig, variabel disiplin kerja mempunyai tingkat signifikan sebesar 0.109 lebih besar dari pada 0,05 . Hal ini berarti $\mathrm{H}_{\mathrm{a} 3}$ ditolak, artinya, disiplin kerja tidak berpengaruh signifikan secara parsial terhadap Kinerja Guru.

Selanjutnya, uji F untuk mengetahui pengaruh variabel-variabel independen secara simultan (bersama-sama) terhadap variabel dependen disajikan pada tabel 4. Hasil uji hipotesis 4 dapat dilihat pada Tabel 4, variabel kompetensi, kompensasi, dan disiplin kerja mempunyai $\mathrm{F}_{\text {hitung }}$ sebesar 52.528 lebih besar dari $F_{\text {tabel }}$ yaitu 2.690. dengan tingkat signifikan sebesar 0.000 lebih kecil dari pada 0,05. Hal ini berarti $\mathrm{H}_{\mathrm{a} 4}$ diterima, dengan kata lain kompetensi, kompensasi dan disiplin kerja berpengaruh signifikan secara simultan terhadap kinerja guru.

Tabel 4. Uji F

ANOVA $^{\mathrm{a}}$

\begin{tabular}{llrrrrr}
\hline & Model & Sum of Squares & df & Mean Square & \multicolumn{1}{c}{ F } & \multicolumn{1}{c}{ Sig. } \\
\hline 1 & Regression & 1498.889 & 3 & 499.630 & 52.528 & $.000^{\mathrm{b}}$ \\
& Residual & 960.673 & 101 & 9.512 & & \\
$\quad$ Total & 2459.562 & 104 & & & \\
\hline
\end{tabular}

a. Dependent Variable: Kinerja Guru

b. Predictors: (Constant), Disiplin Kerja, Kompensasi, Kompetensi

Sumber: Hasil Olah Data Penulis

Tabel 5. Korelasi dan Koefisien Determinasi Model Summary

\begin{tabular}{llrrr}
\multicolumn{5}{c}{ Model Summary } \\
\hline Model & $\mathrm{R}$ & $R$ Square & Adjusted $R$ Square & Std. Error of the Estimate \\
\hline 1 & $.781^{\text {a }}$ & .609 & .598 & 3.08409 \\
\hline a. Predictors: (Constant), Disiplin Kerja, Kompensasi, Kompetensi \\
Sumber: Hasil Olah Data Penulis
\end{tabular}

Tabel 5 menunjukan nilai korelasi (R) sebesar 0,781 atau 78,1\%. Hal ini berarti bahwa hubungan atau korelasi antara faktor-faktor yang mempengaruhi kinerja guru adalah kuat. Selanjutnya, nilai Koefisien determinasi $\left(\mathrm{R}^{2}\right)$ sebesar 0,609 atau 60,9\% menunjukan bahwa kontribusi kompetensi, kompensasi dan disiplin kerja terhadap kinerja guru sebesar 60,9\% sedangkan selebihnya yaitu $39,1 \%$ dipengaruhi oleh faktor-faktor lain diluar model.

\section{Pembahasan}

\section{Pengaruh Kompetensi terhadap Kinerja Guru}

Berdasarkan hasil penelitian, variabel kompetensi berpengaruh signifikan terhadap kinerja guru, kesimpulan ini sejalan dengan penelitian (Rokhman \& Supriyoko, 2020), (Parhi, Jufri, \& Muntari, 2017), (Setianigsih \& Kader, 2018), (Aksinapang, Syamsul Bachri, \& Idris Aziz, 2018), (Suaedah, 2020), (Catio \& Sunarsi, 2020). Berdasarkan hasil penelitian, faktor pendorong terbesar 
guru di Lazuardi GIS dalam meningkatkan kompetensi adalah konsep diri yang dimiliki guru yang bersangkutan, yakni kesadaran bahwa tugas yang diembankan adalah untuk kebaikan dan kepentingan sekolah, dan kesadaran untuk beradaptasi dengan menempatkan diri sebagai bagian dari sistem kerja yang ada. Selanjutnya, dimensi kompetensi guru Lazuardi GIS yang baik adalah kemampuan melakukan dan menyelesaikan pekerjaan tanpa perintah langsung dari pimpinan, dan telah memiliki strategi atau cara-cara tertentu dalam menyelesaikan pekerjaan menjadi lebih efektif dan efisien. Adapun faktor yang dirasakan lemah atau perlu perbaikan pada variabel kompetensi adalah kerjasama dengan rekan untuk bersama-sama menyelesaikan pekerjaan.

Berdasarkan hasil penelitian, sifat individualis cukup mendominasi karakteristik guru, hal ini disebabkan faktor beban kerja masing-masing guru yang harus diselesaikan ditengah waktu yang singkat, dan tanggung jawab lainnya diluar pekerjaan. Faktor kejelasan job description juga belum baik, banyak guru yang merasa bahwa beban kerja atau tugas yang harus dilakukan diluar tanggung jawabnya, sehingga manajemen sekolah seharusnya mempertegas pembagian tugas.

\section{Pengaruh Kompensasi terhadap Kinerja Guru}

Berdasarkan hasil penelitian, variabel kompensasi berpengaruh signifikan terhadap kinerja guru, kesimpulan ini sejalan dengan penelitian (Rokhman \& Supriyoko, 2020), (Parhi et al., 2017), (Aksinapang et al., 2018), (Jayanto et al., 2020), (Presilawati, 2016), (Sari \& Mardjuni, 2018), dan (Habibi, 2013). Berdasarkan hasil penelitian, sebagian besar guru mengakui bahwa pihak sekolah memberikan penghargaan bagi guru yang berprestasi, pelaksanaan pemberian gaji selalu dilakukan tepat waktu, terdapat tunjangan hari raya, tunjangan pendidikan dan dana pensiun bagi guru, mendapat Asuransi kesehatan atau jaminan kesehatan dari pihak sekolah, ada sistem kenaikan gaji bagi Guru yang dapat menunjukan prestasi yang baik, dan pihak sekolah memberikan honor bagi pekerjaan tambahan yang dilakukan guru.

Adapun faktor yang dirasakan lemah atau perlu perbaikan pada variabel kompensasi adalah perlu adanya penyesuaian dana asuransi kesehatan yang diterima Guru dengan biaya kesehatan saat ini, banyak responden yang merasakan bahwa tunjangan kesehatan yang ada perlu ditambah plafonnya sehingga guru merasa tenang dalam bekerja. Guru juga merasa bahwa gaji, tunjangan dan bonus yang diberikan perlu penyesuaian, sebab dengan adanya kenaikan harga-harga yang cukup tinggi, gaji, tunjangan dan bonus yang diberikan perlu penyesuain karena saat ini dirasakan kurang menutupi biaya kebutuhan rumah tangga. Pemberian tunjangan dan bonus juga seharusnya diberikan sesuai dengan kinerja guru, jangan disamakan, agar lebih mendorong guru untuk berkinerja lebih baik.

\section{Pengaruh Disiplin Kerja terhadap Kinerja Guru}

Berdasarkan hasil penelitian, variabel disiplin kerja tidak berpengaruh terhadap kinerja guru, kesimpulan ini sejalan dengan penelitian (Suaedah, 2020), (Catio et al., 2013) yang juga menyatakan bahwa disiplin kerja tidak berpengaruh signifikan terhadap kinerja. Dalam rangka menerapkan 
kedisplinan guru, responden menyatakan bahwa perlu perbaikan komunikasi dengan atasan pada setiap masalah yang dihadapi oleh guru, sebab pada umumnya, masalah indisipliner yang dilakukan oleh guru berkaitan dengan masalah lain yang perlu dijelaskan kepada manajemen.

Guru merasakan bahwa sudah seharusnya mentaati peraturan yang berlaku disekolah, berusaha hadir disekolah lebih awal sebelum jam mengajar dimulai, dan selalu menjaga dan menjunjung tinggi norma-norma yang berlaku disekolah, namun saat ada kesalahan yang berdimensi pada indispliner seperti terlambat hadir, guru dapat menjelaskan bahwa keterlambatan tersebut memiliki alasan yang valid.

\section{KESIMPULAN DAN SARAN}

\section{Kesimpulan}

Berdasarkan hasil penelitian, maka kesimpulan dalam penelitian ini adalah:

1. Variabel kompetensi berpengaruh signifikan terhadap kinerja guru, faktor pendorong terbesar guru di Lazuardi GIS dalam upaya meningkatkan kompetensi adalah konsep diri yang dimiliki guru yang bersangkutan, yakni kesadaran bahwa tugas yang diembankan adalah untuk kebaikan dan kepentingan sekolah, dan kesadaran untuk beradaptasi dengan menempatkan diri sebagai bagian dari sistem kerja yang ada

2. Variabel kompensasi berpengaruh signifikan terhadap kinerja guru, sebagian besar guru mengakui bahwa pihak sekolah memberikan penghargaan bagi guru yang berprestasi, pelaksanaan pemberian gaji selalu dilakukan tepat waktu, terdapat tunjangan hari raya, tunjangan pendidikan dan dana pensiun bagi guru, mendapat Asuransi kesehatan atau jaminan kesehatan dari pihak sekolah, ada sistem kenaikan gaji bagi Guru yang dapat menunjukan prestasi yang baik, dan pihak sekolah memberikan honor bagi pekerjaan tambahan yang dilakukan guru

3. Variabel disiplin kerja tidak berpengaruh terhadap kinerja guru, responden menjelaskan bahwa perlu perbaikan komunikasi dengan atasan pada setiap masalah yang dihadapi oleh guru, sebab pada umumnya, masalah indisipliner yang dilakukan oleh guru berkaitan dengan masalah lain yang perlu dijelaskan kepada manajemen

4. Secara simultan, kompetensi, kompensasi dan disiplin kerja berpengaruh signifikan secara simultan terhadap kinerja guru, hubungan atau korelasi antara faktor-faktor yang mempengaruhi kinerja guru adalah kuat. Kontribusi kompetensi, kompensasi dan disiplin kerja terhadap kinerja guru sebesar 60,9\% sedangkan selebihnya yaitu 39,1\% dipengaruhi oleh faktor-faktor lain diluar model.

\section{Saran}

Saran yang dapat peneliti berikan berdasarkan hasil penelitian adalah: 
1. Manajemen Lazuardi GIS sebaiknya membuat program yang mempererat kerjasama dengan sesama guru, baik dalam bentuk outbond maupun workshop, sebab kerjasama antar guru dalam upaya meningkatkan kompetensi dirasakan belum optimal.

2. Manajemen Lazuardi GIS sebaiknya melakukan evaluasi pada pelaksanaan job description, baik pada tataran dokumen standar of procedur maupun implementasi di lapangan, sebab banyak guru yang merasa bahwa beban kerja atau tugas yang harus dilakukan banyak diluar tanggung jawab.

3. Manajemen Lazuardi GIS perlu melakukan perhitungan kembali dana asuransi kesehatan, dan jika memiliki kemampuan finansial sebaiknya ada kenaikan pada dana asuransi kesehatan bagi guru.

4. Manajemen Lazuardi GIS sebaiknya memasukkan unsur kinerja dalam membagikan insentif tunjangan dan bonus, agar aktivitas kompensasi yang sudah baik tersebut, mampu mendorong guru agar berkinerja lebih baik.

5. Manajemen Lazuardi GIS lebih membuka ruang komunikasi kepada guru-guru yang selama ini dianggap indispliner, pendekatan dengan komunikasi yang intensif diharapkan mampu mengatasi masalah-masalah indispliner.

6. Penelitian selanjutnya diharapkan menambah variabel penelitian yang belum masuk dalam penelitian ini, seperti motivasi kerja, beban kerja, perspekti gender, gaya kepemimpinan, lingkungan kerja dan sebagainya. 


\section{DAFTAR PUSTAKA}

Aksinapang, Syamsul Bachri, \& Idris Aziz. (2018). Pengaruh Kompetensi, Kompensasi dan Lingkungan Kerja Non Fisik Terhadap Kinerja Pegawai Pada PT.BNI (Persero) Tbk Kantor Cabang Utama Palu. Jurnal Katalogis, 6(4), 182-194.

Azmi, F., Sakdiawati, \& Marlibatubara, M. (2019). Pengaruh Disiplin, Kompetensi, dan Motivasi Guru terhadap Kinerja Guru pada Sekolah Menengah Pertama Negeri (SMPN) di Kecamatan Gelumbang Kabupaten Muara Enim. Jurnal Kolegial, 7(1), 76-91.

Catio, M., \& Sunarsi, D. (2020). Analisa Pengaruh Kompetensi, Disiplin Kerja Dan Motivasi Terhadap Kinerja Guru (SMK Sasmita Jaya 1 Pamulang Kota Tangerang Selatan). Equilibrium: Jurnal Pelatihan Pendidikan Dan Ekonomi, 17(02), 1-15. https://doi.org/10.25134/equi.v17i02.ABSTRACT

Catio, M., Yusuf, S., \& Aldy, H. (2013). Pengaruh Disiplin, Kompetensi Dan Kompensasi Terhadap Kinerja Guru Pada Sekolah Islam Terpadu Permata Madani. Inovasi, 140-150.

Ghozali, I. (2011). Aplikasi Analisis Multivariate dengan Program SPSS. Semarang: Badan Penerbit Universitas Diponegoro.

Habibi, B. (2013). Budaya Organisasi, Kompensasi, dan Kompetensi Pedagogik Serta Pengaruhnya terhadap Kinerja Guru. Cakrawala: Jurnal Pendidikan, 711. Retrieved from http://ejournal.upstegal.ac.id/index.php/Cakrawala/article/view/262

Jayanto, Susanto, Y., \& Mulyadi. (2020). Pengaruh Kompensasi Motivasi Dan Disiplin Kerja Terhadap Kinerja Guru Di Sma Negeri Jayaloka Kabupaten Musi Rawas. Adminika, 6(1), 8391. Retrieved from http://journal.poltekanika.ac.id/index.php/adm/article/view/153

Kadtong, M. L., Unos, M., Antok, T. D., \& Midzid, M. A. E. (2018). Teaching Performance and Job Satisfaction Among Teachers at Region XII. SSRN Electronic Journal, 4(1). https://doi.org/10.2139/ssrn.3169846

Kaur, I., Shri, C., \& Mital, K. M. (2019). The Role of Emotional Intelligence Competencies in Effective Teaching and Teacher's Performance in Higher Education. Higher Education for the Future, 6(2), 188-206. https://doi.org/10.1177/2347631119840542

Lathifah, J. (2014). Pengaruh Kompetensi, Kompensasi, Dan Motivasi Terhadap Kinerja Kerja. Jurnal Studia Akuntansi Dan Bisnis, 1(3), 109-120.

Masruroh, U., Thomas, P., \& Latifah, L. (2012). Pengaruh Kompensasi Dan Disiplin Kerja Terhadap Kinerja Guru Ekonomi Sma Negeri Brebes. Economic Education Analysis Journal, 1(2).

Mutakin, T. Z. (2015). Pengaruh Kompetensi, Kompensasi, dan Latar Belakang terhadap Kinerja Guru. Formatif: Jurnal Ilmiah Pendidikan MIPA, 3(2), 145-156. https://doi.org/10.30998/formatif.v3i2.122 
Panjaitan, B. (2016). Pengaruh Insentif, Sertifikasi Guru, dan Disiplin Kerja Terhadap Kinerja Guru. Media Manajemen Jasa, 3(2), 89-107.

Parhi, Jufri, H. A. W., \& Muntari. (2017). Pengaruh Kompetensi dan Kompensasi Kerja Terhadap Kinerja Guru Produktif Sekolah Menengah Kejuruan Negeri di Kabupaten Lombok Barat. Jurnal Ilmiah Profesi Pendidikan, 2(2), 153-163.

Parman, Mahfudnurnajamuddin, Nujum, S., \& Su'un, M. (2020). Effect of Competence , Compensation, Discipline of Work, Work Environment Satisfaction and Performance of Employees in Constructionin the City of Pare-Pare. Journal of Business and Management, 22(2), 53-63. https://doi.org/10.9790/487X-2202035363

Presilawati, F. (2016). Pengaruh Kompensasi Dan Disiplin Kerja Terhadap Kinerja Guru Sma Negeri 6 Banda Aceh. Jurnal Visioner Dan Strategis, 5(2), 83-94. https://doi.org/10.37598/jimma.v6i1.506

Rokhman, A., \& Supriyoko. (2020). Analisis Kinerja Guru Madrasah Ibtidaiyah Ditinjau dari Kompetensi Manajerial Kepala Sekolah, Disiplin Kerja Guru, dan Kompensasi. Media Manajemen Pendidikan, 2(3), 482. https://doi.org/10.30738/mmp.v2i3.6788

Sari, P., \& Mardjuni, S. (2018). Pengaruh Kompetensi, Kompensasi Finansial Dan Disiplin Kerja Terhadap Kinerja Pegawai Distrik Navigasi Kelas I Makassar. Indonesian Journal of Business and Management, 1(1), 53-61.

Setianigsih, W., \& Kader, M. A. (2018). Pengaruh Disiplin Kerja, Kompetensi, Dan Kompensasi Terhadap Kinerja Guru. Jurnal Ilmu Manjemen, 5(20), 313-320.

Suaedah, S. (2020). Pengaruh Kompetensi Profesional, Kompensasi, dan Disiplin terhadap Kinerja Guru. SAP (Susunan Artikel Pendidikan), 5(2), 177-181. https://doi.org/10.30998/sap.v5i2.7698

Sugiyono. (2016). Metode Penelitian Bisnis. Bandung: Alfabeta.

Thaief, I., Baharuddin, A., Priyono, \& Idrus, M. S. (2015). Effect of training, compensation and work discipline against employee job performance: (Studies in the office of PT. PLN (Persero) Service Area and Network Malang). Review of European Studies, 7(11), 23-33. https://doi.org/10.5539/res.v7n11p23 